\title{
2.1. \\ Polityka personalna a relacje międzyludzkie
}

\section{Wprowadzenie}

Ze wszystkich operacyjnych funkcji zarządzania funkcja personalna uległa największym zmianom w ostatnich kilkudziesięciu latach. W miejsce dotychczasowego podejścia do personelu jako przede wszystkim źródła kosztów obecnie coraz częściej dominuje podejście polegające na traktowaniu go jako składnika zasobów przedsiębiorstwa, i to składnika o strategicznej wartości dla firmy [Wiernek 2006, s. 77]. Zmiana stosunku do pracownika, jego istoty i znaczenia $\mathrm{w}$ budowaniu przewagi konkurencyjnej organizacji powoduje zmianę zasad, metod i narzędzi nakierowanych na kształtowanie potencjału kadrowego i zaangażowania organizacyjnego [Juchnowicz 1996, s. 81]. Ma również wpływ na ogólną, opartą na określonych wartościach filozofię organizacji względem jej pracowników - rozumianą w niniejszym opracowaniu jako polityka personalna [Listwan 2005, s. 118 $]^{13}$.

W perspektywie czasu $\mathrm{w}$ podejściu organizacji do polityki personalnej wyraźnie widoczna jest zarówno ciagłość, jak i zmiana. $\mathrm{Z}$ jednej strony, w centrum zainteresowań pozostają wciąż te same lub podobne problemy, związane $\mathrm{z}$ doborem, ocenianiem, wynagradzaniem czy szkoleniem pracowników. Z drugiej jednak strony, zmienia się podejście do rozwiązywania tych kwestii, głównie pod wpływem zmian zachodzących w obszarze technicznych, ekonomicznych, prawnych, czy społeczno-kulturowych uwarunkowań zarządzania zasobami pracy [Pocztowski 2008, s. 19].

Prowadząc rozważania $\mathrm{w}$ zakresie polityki personalnej, należy pamiętać, że zasadnicze fazy rozwoju praktyk personalnych i myśli teoretycznej - odnoszonych do ludzi w organizacji - odpowiadały głównym szkołom i nurtom nauki o zarządzaniu [Listwan 2010, s. 19]. Większość badaczy przyjmując taką podstawę, tworzy systematyki oparte

\footnotetext{
${ }^{13} \mathrm{~W}$ literaturze przedmiotu funkcjonuje wiele pojęć związanych z określeniem działań organizacji względem pracowników. Część z nich ma swoje uzasadnienie w ewolucji teorii organizacji i zarządzania, inne pojawiają się w charakterze synonimów lub określeń autorskich. Z uwagi na rozbieżności terminologiczne w niniejszym opracowaniu na określenie stosunku organizacji do zatrudnianych w niej ludzi wykorzystywany będzie termin „polityka personalna”, rozumiany jako wyznawane przez organizację wartości dotyczące sposobu, w jaki powinno się traktować ludzi i nimi zarządzać; ogólne określenie filozofii organizacji i jej wartości w zakresie zarządzania pracownikami [Padzik 2002, s. 67].
} 
na chronologii. Na przykład T. Listwan wymienia trzy fazy rozwoju funkcji personalnej, określając je jako: operacyjną, taktycznomenedżerską oraz strategiczną [por. Szałkowski 2000, s. 19]. A. Pocztowski omawiając główne modele teoretyczne i trendy rozwojowe w obszarze funkcji personalnej, dzieli je zaś na trzy modele: tradycyjny koniec XIX i początek XX w., stosunków międzyludzkich - lata 30. i 40. $\mathrm{XX}$ w. oraz model zasobów ludzkich - lata 50. i 60. XX w. [por. Pocztowski 2008, s. 20].

Celem niniejszego rozdziału nie jest jednak analiza ewolucji w zakresie zarządzania kadrami w organizacji, a wskazanie, jak zmiany w zakresie polityki personalnej (stosunku do pracownika, rozumienia jego roli etc.) wpływają na zachowania organizacyjne. Dlatego też, zgodnie z założeniami opracowania, poniżej omówione zostaną modele polityki personalnej, charakterystyczne dla organizacji określanych jako tradycyjne, współczesne i przyszłości, przy czym podział ten ma charakter umowny. Model polityki personalnej organizacji tradycyjnej, pomimo iż jest charakterystyczny dla początku i połowy XX w., wciąż występuje $\mathrm{w}$ organizacjach. A co się $\mathrm{z}$ tym wiąże, nie wszystkie organizacje współczesne działają, opierając się na tych samych wytycznych. Tak więc niniejsze rozważania podzielone na trzy części odpowiadające modelom nie są zdeterminowane temporalnie. Model administrowania zatrudnieniem - charakterystyczny dla „wczoraj”, zarządzania zasobami ludzkimi - w kontekście „dzisiaj” oraz kapitału ludzkiego - w odniesieniu do ,jutra”, należy traktować jako konstrukty teoretyczne, stanowiące pretekst do analizy zachowań organizacyjnych w organizacjach o odmiennym stosunku do zatrudnionych w niej ludzi.

Każda $\mathrm{z}$ części tego rozdziału składa się $\mathrm{z}$ trzech elementów: analizy najważniejszych koncepcji i tendencji charakterystycznych dla danego okresu, w których należy upatrywać źródeł danego modelu, omówienia wybranych obszarów polityki personalnej wynikających z modelu oraz dywagacji na temat ich konsekwencji dla zachowań ludzi w organizacji.

\section{Pracownicy w organizacji tradycyjnej}

W przypadku polityki personalnej trudno mówić o spójnym „wczoraj”. Sposób, w jaki traktowano pracowników i traktuje się do dziś w organizacjach określanych jako „tradycyjne”, jest konsekwencją zmian zachodzących $\mathrm{w}$ organizacji na przestrzeni lat. Warto zatem prześledzić ciąg zdarzeń, które doprowadziły do określonego postrzegania istoty i znaczenia pracownika w tego typu organizacjach. 
W okresie dynamicznego rozwoju przemysłu na początku XX w. w ramach tzw. szkoły naukowego zarządzania zarysował się tradycyjny model funkcji personalnej. Jego podstawowymi zagadnieniami były podział i wydajność pracy, fizyczne warunki środowiska fabrycznego, dyscyplina pracy $\mathrm{i}$ finansowanie wynagrodzenia. Zainteresowania naukowe skupiały się na pracy wykonawczej, i to pracownik pozostawał $\mathrm{w}$ centrum uwagi jako przedmiot badania ${ }^{14}$. Człowiek - pracownik postrzegany był jako trybik w maszynie, do której musiał pasować [Listwan 2010, s. 19]. Owo dopasowanie możliwe było dzięki dwóm elementom: podziałowi pracy i naukowemu doborowi pracowników i szkoleniu.

Jeden $\mathrm{z}$ badaczy $\mathrm{z}$ tego okresu $\mathrm{Ch}$. Babbage zalet podziału pracy upatrywał przede wszystkim w czterech czynnikach: skróceniu czasu potrzebnego na naukę, unikaniu przechodzenia od jednej czynności do drugiej, wprawie nabytej wskutek częstego powtarzania tych samych czynności oraz korzyści wynikających $\mathrm{z}$ możliwości lepszego przystosowania narzędzi i maszyn do wykonywania określonych czynności [Babbage, za: Kurnal 1972, s. 23-26].

Podział pracy miał swoje uzasadnienie ekonomiczne, obniżał koszty produkcji, jednak zdaniem Ch. Babbage'a wyjaśnienie takie byłoby niepełne, przy pominięciu faktu, iż „dzieląc pracę na różne czynności, których każda wymaga odmiennego stopnia umiejętności i siły, przedsiębiorca może zaangażować dokładnie taką ilość umiejętności i siły, jaka jest potrzebna do spełnienia każdej czynności; gdyby natomiast cała praca była wykonywana przez jednego robotnika, to robotnik ten musiałby posiadać umiejętności wystarczające na wykonanie najtrudniejszych czynności oraz siłę wystarczającą na wykonanie najcięższych operacji spośród tych, które wchodzą w grę w przypadku danego rzemiosła" [Babbage za: Kurnal 1972, s. 28].

Taka charakterystyka zadań, jakie stawiano przed pracownikiem, określała bardzo wyraźnie wymagania względem niego. Proste czynności były wykonywane przez pracownika posiadającego „dokładnie taką ilość umiejętności i siły”, by im sprostać. Podział pracy wymuszony poniekąd niskimi kwalifikacjami siły roboczej podtrzymywał ten stan rzeczy. Pracownik nie miał się rozwijać wszechstronnie, zdobywać kwalifikacji, a jedynie „wprawiać” w wykonywanie czynności. Takie działanie z pewnością utrwalały postawę pasywności, apatii i braku

\footnotetext{
${ }^{14}$ Określenie ,przedmiot badania” użyte zostało celowo, jego uzasadnienie stanowią przytoczone w dalszej części rozdziału słowa F. Fayola.
} 
zaangażowania, a rozwój ograniczony został tylko do umiejętności wykonawczych.

Obowiązkiem kadry kierowniczej był naukowy dobór robotników, a następnie stopniowe rozwijanie ich umiejętności w zakresie ograniczonym przez stanowisko. Sam F. Taylor tak o tym pisał: „Robotnicy poddawani są badaniu, może się to wydać niedorzecznością, ale są oni badani zupełnie tak samo jak maszyny, które badano już dawniej i jeszcze dokładniej bada się obecnie. W przeszłości przedmiotem bardzo wielu badań były maszyny, a bardzo niewielu robotnicy, natomiast w warunkach naukowego zarządzania robotnik staje się przedmiotem o wiele staranniejszych i dokładniejszych badań niż maszyny. Po zbadaniu robotnika i poznaniu jego możliwości postępujemy jak przyjaciel wobec przyjaciela, starając się wydobyć na jaw i rozwijać jego zdolności” [Taylor, za: Kurnal 1972, s. 65].

Warto zastanowić się nad przyczyną takiego traktowania pracowników w owym czasie. W literaturze przedmiotu element ten jest $\mathrm{w}$ zasadzie pomijany $\mathrm{w}$ przekonaniu, że to, co oczywiste, nie wymaga powtórzenia. Przedmiotowe traktowanie pracowników tylko częściowo było spowodowane orientacją na zysk przedsiębiorców. Należy bowiem pamiętać, że w okresie rewolucji przemysłowej wzrost zapotrzebowania na siłę roboczą był tak znaczny, że rekrutowała się ona przede wszystkim z ludności wsi, imigrantów czy też osób dotychczas wykluczonych z sytuacji pracy. Najlepszym przykładem takiego przyspieszonego rozwoju jest miasto Łódź, które $\mathrm{z}$ małej osady jeszcze na początku XIX w. stało się w 1850 r. drugim po Warszawie miastem pod względem liczby mieszkańców w Królestwie Polskim. W przeciągu stulecia liczba ludności zwiększyła się w Łodzi 600-krotnie, z niecałego tysiąca w 1815 do 600 tys. w 1915 r. [Wojalski 1998, s. 23]. Taki rozwój możliwy był tylko dzięki napływowi mieszkańców $\mathrm{z}$ okolicznych wsi. Niewykwalifikowanym, niepiśmiennym i nieprzyzwyczajonym do rygoru organizacji ludziom należało tak zorganizować pracę, by nie tylko nie przekraczała ich możliwości, ale również pozwalała na szybkie i sprawne wywiązywanie się $\mathrm{z}$ powierzonych zadań. Łatwiej taką „nieprzygotowaną” jednostkę nauczyć jednej, prostej czynności, a w razie konieczności zastapić ją kolejna, nie tracąc czasu na szkolenia i przyuczanie. Pracowników nie traktowano jak partnerów, lecz jako narzędzia wymagające dopasowania do procesu produkcji. Szkoła naukowa dążyła przede wszystkim do zwiększenia wydajności pracy ludzi i maszyn oraz do podporządkowania organizacji przedsiębiorstwa „od dołu ku górze”. 
Należy jednak wyraźnie zaznaczyć zmianę w podejściu do pobudzania ludzi do wydajniejszej pracy. W miejsce stosowanego dotychczas (w erze przedindustrialnej) mechanizmu zagrożenia utratą pracy postulowano stosowanie bodźców finansowych i nagradzanie wyróżniających się pracowników. Zdaniem A. Pocztowskiego za kluczowy element teorii naukowego zarządzania w odniesieniu do problemów personalnych należy uznać zasadę, w myśl której pracownicy produkujący więcej powinni być lepiej nagradzani [Pocztowski 2008, s. 17]. Takie podejście powodowało $\mathrm{w}$ konsekwencji koncentrację na potrzebach podstawowych, takich, których zaspokojenie jest możliwe właśnie dzięki bodźcom finansowym.

Pewnym uzupełnieniem omawianego podejścia był kierunek administracyjny, w którym przedmiotem zainteresowania uczyniono sferę zarządcza, natomiast w zakresie funkcji personalnej podejmowano dalej problematykę podziału pracy (funkcji), ale również współdziałania, autorytetu, dyscypliny pracy i odpowiedzialności oraz stabilności personelu i wynagrodzenia [Listwan 2010, s. 20]. Warto zauważyć, że niemal każdą z czternastu zasad administracji H. Fayola zaliczyć można do wytycznych dla polityki personalnej ówczesnych przedsiębiorstw (por. tab. 1).

Tabela 1. Wytyczne dla polityki personalnej w zasadach administracji H. Fayola

\begin{tabular}{|l|l|}
\hline Podział pracy & $\begin{array}{l}\text { „Podział pracy odnosi się nie tylko do zadań technicznych, } \\
\text { lecz do wszystkich prac, które absorbują mniejszą lub większą } \\
\text { liczbę ludzi i wymagaja różnorodnych uzdolnień. } \\
\text { konsekwencją tego jest specjalizacja czynności } \\
\text { i rozgraniczenie kompetencji” }\end{array}$ \\
\hline Autorytet & $\begin{array}{l}\text { „Nie można sobie wyobrazić autorytetu bez poczucia } \\
\text { odpowiedzialności, czyli autorytetu bez uznania potrzeby } \\
\text { stosowania nagród i kar, towarzyszących wykonywaniu } \\
\text { władzy. (...) odważne podejmowanie i ponoszenie } \\
\text { odpowiedzialności zapewnia pracownikowi poważanie” }\end{array}$ \\
\hline Dyscyplina & $\begin{array}{l}\text { „Dyscyplina jest poszanowaniem przepisów dotyczących } \\
\text { posłuszeństwa, pilności, pracowitości i zewnętrznych oznak } \\
\text { uszanowania. Obowiązuje ona tak najwyższych przełożonych, } \\
\text { jak i najskromniejszych pracowników. Najskuteczniejszymi } \\
\text { środkami służącymi do jej wdrożenia i utrzymania są: dobrzy } \\
\text { przełożeni wszystkich szczebli, jasne i sprawiedliwe umowy, } \\
\text { sprawiedliwie stosowane nagrody i kary” }\end{array}$ \\
\hline $\begin{array}{l}\text { Jedność } \\
\text { rozkazodawstwa }\end{array}$ & „Podwładni nie znoszą dwoistości rozkazodawstwa” \\
\hline $\begin{array}{l}\text { Jednolitość } \\
\text { kierownictwa }\end{array}$ & $\begin{array}{l}\text { „Jednolitość kierownictwa wiąże się z dobrą organizacją pracy } \\
\text { zespołu. Jeden przełożony i jeden plan dla osiagnnięcia celu” }\end{array}$ \\
\hline
\end{tabular}




\begin{tabular}{|l|l|}
\hline $\begin{array}{l}\text { Podporządkowanie } \\
\text { interesów } \\
\text { osobistych } \\
\text { interesowi ogółu }\end{array}$ & $\begin{array}{l}\text { „Środkami wiodącymi do tego celu są: stałość charakteru i } \\
\text { dobry przykład przełożonego, możliwie najsprawiedliwsze } \\
\text { umowy, czujny nadzór” }\end{array}$ \\
\hline Wynagrodzenie & $\begin{array}{l}\text { „Przy określeniu formy zapłaty dąży się do tego, aby: } \\
\text { zapewniała sprawiedliwe traktowanie, zachęcała do } \\
\text { gorliwości, wynagradzając celowe wysiłki, nie prowadziła do } \\
\text { przesady w wynagradzaniu, przekraczając racjonalne granice” }\end{array}$ \\
\hline Centralizacja & $\begin{array}{l}\text { „W każdym organizmie zwierzęcym (czy społecznym) } \\
\text { obserwacje docierają do mózgu i to w mózgu formułowane są } \\
\text { rozkazy wprawiające w ruch wszystkie części organizmu” }\end{array}$ \\
\hline Hierarchia & $\begin{array}{l}\text { „Uszeregowanie przełożonych, od władzy najwyższego } \\
\text { szczebla aż do kierownictwa najniższego szczebla” }\end{array}$ \\
\hline Ład & $\begin{array}{l}\text { „Lad doskonały wymaga, aby miejsce odpowiadało } \\
\text { pracownikowi i aby pracownik odpowiadał danemu miejscu; } \\
\text { właściwy człowiek na właściwym miejscu” }\end{array}$ \\
\hline $\begin{array}{l}\text { Ludzkie } \\
\text { traktowanie } \\
\text { pracowników }\end{array}$ & $\begin{array}{l}\text { „Ludzkie, a nie «sprawiedliwe», ponieważ sprawiedliwość } \\
\text { polega na realizowaniu ustalonych przepisów, lecz w } \\
\text { przepisach nie można wszystkiego przewidzieć; często trzeba } \\
\text { je interpretować albo uzupełnić” }\end{array}$ \\
\hline $\begin{array}{l}\text { Stabilizacja } \\
\text { personelu }\end{array}$ & $\begin{array}{l}\text { „Potrzeba pewnego czasu na to, by pracownik zaznajomił się } \\
\text { ze swą nową praca i stopniowo doszedł do właściwego jej } \\
\text { wykonywania, choćby nawet posiadał on potrzebne do tego } \\
\text { uzdolnienia” }\end{array}$ \\
\hline Inicjatywa & $\begin{array}{l}\text { „Dzięki inicjatywie wzrasta gorliwość i energia pracowników } \\
\text { na wszystkich szczeblach organizacji”15 } \\
\text { przarmonia, zgranie personelu - to czynniki dające siłę }\end{array}$ \\
\hline
\end{tabular}

Źródło: Opracowanie własne, wybór wyjątków na podstawie: H. Fayol, Ogólne zasady administracji, za: J. Kurnal, Twórcy naukowych podstaw organizacji. Wybór pism, PWE, Warszawa, s. 285-314.

W centrum badań kierunku administracyjnego postawiono funkcję zarządczą, a jednym $\mathrm{z}$ głównych zadań kierownika było tworzenie warunków wydajnej pracy pracownika. Cel ten starano się jednak wciąż osiagnnąć niejako zgodnie $\mathrm{z}$ założeniami Teorii $\mathrm{X}$ McGregora, w myśl której pracownicy nie chcą pracować, muszą być zatem ściśle nadzorowani i konieczne jest wprowadzenie kompleksowego systemu kontroli, potrzebna jest także hierarchiczna struktura i skrupulatna kontrola na każdym poziomie. Zgodnie $\mathrm{z}$ tą teoria pracownicy są

15 Jednak zanim pracownik wykaże się inicjatywą i kreatywnością, to musi nauczyć się rekomendowanego sposobu wykonywania pracy. Wtedy i tylko wtedy zdaniem Fayola wolno mu proponować własne rozwiązania i je wykorzystywać [por. H. Fayol, s. 290]. 
pozbawieni ambicji i wykazują się niską inicjatywą, będą więc dążyć do unikania odpowiedzialności tak często, jak to możliwe, a ich jedynym źródłem motywacji jest wynagrodzenie. ${ }^{16}$ Koncentrację na sferze finansowej widać wyraźnie w pracach powstających w tamtym okresie.

Tak szeroko nakreślone tło historyczne pozwala na stwierdzenie, że klasyczne teorie organizacji i zarządzania stały się podstawą dla modelu polityki personalnej określanego jako administrowanie zatrudnieniem, charakterystycznego dla organizacji tradycyjnej. Choć podejście to zostało zainicjowane i upowszechnione na początku XX w., a rozwijało się do lat 60 . ubiegłego wieku, to wykorzystywane jest w niektórych organizacjach do dziś. Jego głównymi cechami są (Oleksyn 2008, s. 20):

- realizacja funkcji kadrowych przez komórki kadrowe,

- ograniczenie funkcji kadrowych do najbardziej podstawowych i najbardziej niezbędnych (rekrutacja i dobór, ewidencja osobowa, elementarne szkolenia, naliczanie wynagrodzeń i podatków, obsługa socjalna, sprawozdawczość),

- postrzeganie prowadzenia akt i ewidencji osobowej pracowników jako szczególnie ważnej i odpowiedzialnej funkcji kadrowej, podobnie jak wzmacnianie formalnej dyscypliny pracy i ograniczanie absencji pracowników,

- pełnienie przez komórkę kadrową głównie funkcji obsługowej, nieangażowanie się w zarządzanie strategiczne,

- rola działu kadr jest stosunkowo mała,

- kierownicy liniowi odgrywają w zarządzaniu kadrami dominującą rolę,

- pracownicy postrzegani wciąż jako przedmiot, nie podmiot zarządzania,

- metody, techniki i narzędzia zarządzania kadrami i badania efektywności pracy są słabe (często nie stosuje się żadnych metod i technik),

\footnotetext{
${ }^{16}$ Teoria X i Y to teoria motywacji stworzona i rozwinięta przez D. McGregora na MIT Sloan School of Management w latach 60. XX w. Opisuje ona dwa zupełnie odmienne podejścia $\mathrm{w}$ stosunku do motywacji pracowników. Według Teorii X pracownicy sa z natury leniwi, nie chcą wykonywać swojej pracy, należy ich więc do tego zmuszać i poddawać ścisłej kontroli. Natomiast według Teorii Y pracownicy mogą być ambitni, wykazywać się motywacją być chętni do podjęcia większej odpowiedzialności, stosować samokontrolę, być samodzielni i sprawdzać się, działając autonomicznie, należy im tylko stworzyć do tego odpowiednie warunki [więcej na temat Teorii X Y w: Robbins, Coulter 2004, s. 51].
} 
- dąży się do egzekwowania pracy głównie poprzez polecenia administracyjne i kontrolę.

Model administrowania zatrudnieniem przekłada się na całość działań organizacji względem zatrudnionych w niej ludzi. Konsekwencje te łatwo można zaobserwować w odniesieniu do poszczególnych obszarów polityki personalnej (por. tab. 2).

Tabela 2. Polityka personalna w modelu administrowania zatrudnieniem

\begin{tabular}{|l|l|}
\hline \multicolumn{1}{|c|}{$\begin{array}{c}\text { OBSZAR } \\
\text { POLITYKI } \\
\text { PERSONALNEJ }\end{array}$} & \multicolumn{1}{|c|}{ DZIALANIA CHARAKTERYSTYCZNE DLA MODELU } \\
\hline $\begin{array}{l}\text { Podmiot działań } \\
\text { i rola pracownika }\end{array}$ & $\begin{array}{l}\text { Pracownicy traktowani jak „trybiki w maszynie” } \\
\text { Podmiotem działań jest organizacja i jej cele, pracownicy } \\
\text { traktowani są przedmiotowo } \\
\text { Główne zadania w obszarze personalnym związane są z funkcją } \\
\text { administracyjną }\end{array}$ \\
\hline $\begin{array}{l}\text { Polityka } \\
\text { zatrudnienia }\end{array}$ & $\begin{array}{l}\text { Planowanie zatrudnienia koncentruje się na zapewnieniu } \\
\text { ciagłości pracy } \\
\text { Rekrutacja prowadzona na szeroką skalę, w procesie selekcji } \\
\text { bada się ,dopasowanie” kandydata do specyfiki stanowiska } \\
\text { pracy } \\
\text { Proste i jasno określone wymagania pracy }\end{array}$ \\
\hline $\begin{array}{l}\text { Szkolenie } \\
\text { i rozwój }\end{array}$ & $\begin{array}{l}\text { Szkolenia podstawowe związane ze stanowiskiem pracy } \\
\text { Ograniczone możliwości awansu i rozwoju } \\
\text { Kierunek i tempo rozwoju wyznaczają aktualne potrzeby } \\
\text { organizacji }\end{array}$ \\
\hline $\begin{array}{l}\text { Motywacja } \\
\text { i ocena }\end{array}$ & $\begin{array}{l}\text { Podejście zgodne z Teorią X: ,ludzie nie chcą pracować” } \\
\text { Wykorzystywanie wyłącznie finansowych instrumentów } \\
\text { motywacji } \\
\text { Motywacja przez zagrożenie karą lub utratą pracy } \\
\text { Ocena wykorzystująca mierniki ilościowe } \\
\text { Ocena pracownika związana z kontrolą bieżących czynności }\end{array}$ \\
\hline
\end{tabular}

Źródło: Opracowanie własne.

Polityka zatrudnienia w omawianym modelu koncentruje się na zapewnieniu ciągłości działań, ale w ujęciu krótkookresowym. Jeśli z jakiegoś powodu, na przykład odejścia pracownika, powstanie wakat, wszczęta zostaje procedura rekrutacyjna. Nie tworzy się tu długookresowych planów następstw, w związku z czym awans ma miejsce wówczas, gdy zwolni się miejsce na wyższym stanowisku. Takie podejście powoduje bierność pracownika w kontekście kształtowania własnej kariery zawodowej. Może spędzić w danej organizacji całe życie, pracując na tym samym stanowisku, lecz równie dobrze może awansować, przy czym nie ma wpływu na tempo rozwoju. 
System motywacji $\mathrm{w}$ organizacji tradycyjnej jest prosty $\mathrm{i}$ nie wykorzystuje zaawansowanych narzędzi. Nagradzana jest wydajność, a nie jakość czy kreatywność. Zgodnie z Teorią X ludzi „zmusza się” do pracy poprzez ciagłą kontrolę i zachęty finansowe. W takiej organizacji nie oczekuje się od pracowników kreatywności, zaangażowania w sprawy organizacji, a jedynie efektywnego wykonywania swoich zadań. Niektóre jednostki doskonale odnajdują się w takiej formule pracy. Inne z biegiem czasu przyzwyczajają się do niej, przyjmując postawę bierności i apatii. Natomiast pracownicy aktywni, stale potrzebujący stymulacji najczęściej - jeśli tylko sytuacja osobista im na to pozwala - odchodzą, a tym samym ryzyko zmian zostaje odsunięte.

Pomimo iż taki rodzaj polityki personalnej jest dość anachroniczny i wydaje się mało prawdopodobny w dzisiejszych czasach, należy zaznaczyć, że wciąż wcale nie rzadko można go spotkać w dwóch rodzajach organizacji: silnie zbiurokratyzowanych, na przykład w sferze budżetowej, oraz w wielkich przedsiębiorstwach produkcyjnych.

Pozostawiając na uboczu rozważań administrację publiczną, gdzie zwyczajne warunki rynkowe wydają się nie mieć znaczenia, warto przyjrzeć się nieco bliżej właśnie dużym zakładom produkcyjnym i realizowanej tam obecnie polityce personalnej. Organizacje takie wydaja się spełniać niemal w zupełności wytyczne administrowania zatrudnieniem. Wystarczy prześledzić składane przez nie oferty pracy. Poszukiwani są najczęściej pracownicy posiadający zdolności manualne, dobrą kondycję fizyczną $\mathrm{i}$ gotowi do podjęcia pracy w systemie trzyzmianowym. W zamian moga oczekiwać wynagrodzenia zasadniczego i premii, pakietu czasowych świadczeń socjalnych, zatrudnienia na podstawie umowy o pracę tymczasową na pełny etat i możliwości zdobywania doświadczenia zawodowego w renomowanej firmie produkcyjnej ${ }^{17}$.

Podobne $\mathrm{w}$ treści ogłoszenie można by $\mathrm{z}$ pewnością zamieścić przed ponad 100 laty. Jedna różnica jest bardzo istotna. Dziś w takiej organizacji na szczeblu podstawowym pracuje się zazwyczaj na podstawie umowy czasowej. Brak możliwości rozwoju i w zasadzie żadna możliwość uczestnictwa w życiu organizacji sprawia, że nawet w XXI w., w dobie, gdy pojęcie kapitału ludzkiego zdaje się panować niepodzielnie, wciąż są organizacje traktujące pracowników przedmiotowo. Niczym u Taylora $\mathrm{w}$ procesie selekcji bada się ich

\footnotetext{
17 Przytaczane zapisy oferty pracy powstały na podstawie analizy ofert pracy dla pracowników taśmy montażowej, np. produkcja ekranów LCD (por. oferty w serwisach Money.pl, Job.pl dla hasła: montaż TV LCD).
} 
dopasowanie do maszyny i uczy jednego właściwego sposobu wykonywania pracy. Sa to zakłady pracy bardzo specyficzne, niepodlegające $\mathrm{w}$ zasadzie modyfikacjom.

Organizacje tradycyjne funkcjonują od lat i z pewnością długo jeszcze będą miały znaczny udział w rynku. Tym bardziej należy zastanowić się nad tym, jakiego rodzaju pracowników ,produkują”. Postawa roszczeniowa $\mathrm{w}$ połączeniu $\mathrm{z}$ biernością osób długotrwale przebywających w takim środowisku dyskwalifikuje je w zasadzie na rynku pracy. $\mathrm{O}$ ile bowiem są w stanie zmienić pracodawcę i wykonywać nawet inne czynności, wykorzystując ten sam schemat zatrudnienia (niczym robotnicy u Taylora, ale w XXI w.), to już przejście do nowego modelu i adaptacja do jego warunków często okazuje się przerastać ich możliwości. Taka prosta konstatacja jest niestety bardzo często pomijana czy lekceważona w procesie zarządzania. Zamykane są duże zakłady pracy, restrukturyzowane przedsiębiorstwa o kilkudziesięcioletniej tradycji, wszystko zgodnie $\mathrm{z}$ rachunkiem ekonomicznym i w odniesieniu do warunków otoczenia. Od ludzi oczekuje się natomiast natychmiastowego odnalezienia się w nowej sytuacji zawodowej. Oni jednak otrzymane odprawy czy zapomogi traktują jako kolejną gratyfikację finansową, którą moga zaspokoić swoje potrzeby. Nie są to potrzeby związane $\mathrm{z}$ podniesieniem własnych kwalifikacji czy aktywizacją zawodową. Do takich działań nikt ich ani nie przyzwyczaił, ani ich nie nauczył. W tym właśnie tkwi największe niebezpieczeństwo funkcjonowania organizacji tradycyjnych. Dają złudne w dzisiejszych czasach poczucie pewności zatrudnienia, wykształcając w pracownikach postawę roszczeniową.

\section{Organizacje współczesne}

O ile tradycyjną politykę personalną ukształtowały w głównej mierze dokonania przedstawicieli klasycznej szkoły zarządzania (naukowe zarządzanie i kierunek administracyjny), to podejście współczesne swoje źródła ma w latach 30. ubiegłego wieku. Wtedy to, wraz $\mathrm{z}$ rozwojem nauki o organizacji i przemianami w sferze praktyki zarządzania, podejście tradycyjne okazało się w znacznym stopniu niewystarczające. Kadra menedżerska musiała stawić czoła takim wyzwaniom, jak spadek wydajności, duża fluktuacja w miarę wzrostu dobrobytu pracowników czy też szerzej - przemianom społecznoobyczajowym. Zaczęto zatem zastanawiać się, gdzie należy upatrywać źródeł sukcesu w kierowaniu personelem.

Odpowiedzi na to pytanie przynosiły prace z zakresu psychologii i socjologii, które coraz mocniej w tamtych czasach akcentowały kontekst 
społeczny. Konieczność dostrzegania sfery duchowej i potrzeb grupowych pracowników, jako ważnego źródła satysfakcji prowadzącej do wzrostu efektywności pracy, leżała u podstaw nurtu stosunków międzyludzkich, na czele $\mathrm{z}$ poglądami E. Mayo oraz tzw. szkoły behawioralnej, tworzonej przez D. McGregora, R. Likerta i Ch. Argirisa (Listwan 2010, s. 20).

Badania E. Mayo w Western Electric's Hawthorne wykazały, że odpowiednia organizacja pracy oraz odpowiednia płaca nie prowadzą do wzrostu wydajności pracy. Kluczowym elementem są bowiem takie czynniki, jak: interakcje między pracownikami, nacisk grupy czy normy społeczne. Prowadzone później w tym nurcie badania wykorzystywały również prace behawiorystów. Celem dociekań była analiza napięć powstających na styku tradycyjnych struktur organizacyjnych i indywidualnych potrzeb pracowników. Wykorzystując dorobek nauki o zarządzaniu, psychologii i socjologii pracy, starano się stworzyć model organizacji idealnej: efektywnej i zarazem humanistycznej (Pocztowski 2008, s. 18).

Zmiany te nie przynosiły jednak zakładanych rezultatów. Początkowo troska wykazywana wobec robotników zwiększała wydajność i satysfakcję $\mathrm{z} \operatorname{pracy}^{18}$, jednak z wraz z postępującymi zmianami społecznymi i rosnącą świadomością pracowników, coraz lepiej wykwalifikowanych, działania takie uznawane były za niewystarczające. Zaczęto dostrzegać, że postawa jednostki i związana $\mathrm{z}$ nią motywacja i zaangażowanie do pracy są procesami bardzo złożonymi i wymagają zastosowania wielu złożonych bodźców i oddziaływań. Szukano swoistej syntezy między dotychczasowymi koncepcjami.

$\mathrm{Na}$ tym właśnie gruncie rozwijało się podejście określane jako zarządzanie personelem, którego głównymi cechami były: orientacja na pracowników, tworzenie i rozwój wielofunkcyjnych, interdyscyplinarnych i zintegrowanych pionów personalnych wykorzystujących zaawansowane metody, techniki i narzędzia pracy oraz orientacja na środowisko społeczne, uwzględniająca profilaktykę i higienę pracy (por. Oleksyn 2008, s. 21). Potrzebą czasów okazała się jednak większa orientacja biznesowa utrwalająca stanowisko, zgodnie z

18 Optymizm związany z sukcesami nurtu stosunków międzyludzkich wypływał bezpośrednio $\mathrm{z}$ badań E. Mayo w zakładzie włókienniczym oraz zakładach produkcyjnych Hawthorne, szerzej na ten temat: E. Mayo, Pierwsze badania oraz Hawthorne $i$ Western electric Company, wybór tekstów zamieszczony w: J. Kurnal (red.), Twórcy naukowych podstaw organizacji. Wybór pism, PWE, Warszawa 1972. 
którym funkcja personalna to obszar zarządzania. Rozpoczęła się era zarządzania zasobami ludzkimi - wyznaczająca kierunek polityki personalnej współczesnych organizacji.

W tym ujęciu zarządzanie zasobami ludzkimi jest określoną koncepcją zarządzania w obszarze funkcji personalnej, w której zasoby ludzkie postrzega się jako aktywa organizacji i źródło przewagi konkurencyjnej. ${ }^{19}$ Jej najważniejszymi cechami jest postulowanie integracji spraw personalnych ze sprawami biznesowymi, aktywizacja kierownictwa liniowego w rozwiązywaniu problemów oraz kształtowanie kultury organizacyjnej sprzyjającej integracji procesów pracowniczych i budowaniu zaangażowania pracowników jako narzędzia osiągania celów (por. Pocztowski 2008, s. 34). Takie podejście bardzo wyraźnie wpływa na politykę personalną, a tym samym na zachowania ludzi w organizacji (por. tab. 3). Warto zastanowić się zatem nad niektórymi konsekwencjami tych zmian.

W modelu zarządzania zasobami ludzkimi postrzeganie funkcji personalnej $\mathrm{w}$ wymiarze strategicznym zdeterminowane jest wieloma czynnikami. Część z nich ma swoje źródła w otoczeniu organizacji (duża dynamika zmian, globalizacja, rosnąca konkurencja i jej zasięg, silny wpływ państwa na zatrudnienie, np. poprzez legislację). Inne natomiast powiązane są $z$ samą organizacją $i$ jej oczekiwaniami względem pracowników, np. wzrostem złożoności gospodarki, restrukturyzacją przedsiębiorstw, decentralizacją zarządzania, dostrzeganiem roli kultury organizacyjnej, zmianami w technologii wytwarzania, presją na większą sprawność i kreatywność, dążeniem do większej elastyczności i samodzielności w pracy, oczekiwaniem odpowiedzialności i lojalności względem organizacji oraz należytego powiązania i dostosowania organizacji i jednostki (Listwan 2010, s. 22-23).

Podstawowe zadania w zakresie zarządzania personelem wyznaczane są przez cele organizacji, jednak $\mathrm{z}$ uwzględnieniem możliwości i potrzeb pracownika. Plany zatrudnienia tworzone są w perspektywie długookresowej. Przyjęcie do organizacji odbywa się nie tylko na podstawie już posiadanych kwalifikacji i umiejętności, uwzględnia bowiem również potencjał rozwojowy jednostki.

\footnotetext{
19 Ta część opracowania zawiera pewien skrót, dotyczący ewolucji funkcji personalnej od szkoły stosunków międzyludzkich do zarządzania zasobami ludzkimi. Zabieg ten podyktowany jest troską o spójność wywodu i niezawieranie w nim treści mniej istotnych z punktu widzenia omawianej problematyki. Dlatego też zainteresowanych relacją między humanizacją pracy, zarządzaniem personelem a zarządzaniem zasobami ludzkimi odesłać należy do pracy: M. Armstrong, Zarzadzanie zasobami ludzkimi, Oficyna ekonomiczna, Dom Wydawniczy ABC, Kraków 2001, s. 25-27.
} 
Wykorzystywanie $\mathrm{w}$ procesie selekcji zaawansowanych narzędzi umożliwia stworzenie już na wstępie planu rozwoju i ścieżki kariery. Wypełnienie warunków kontraktu pozwala pracownikowi związać się $\mathrm{z}$ organizacją na długie lata. Będzie się rozwijał $\mathrm{w}$ tempie i kierunku zdeterminowanym strategią firmy. Zwiększenie nakładów na rozwój zasobów ludzkich sprawia, że fluktuacja w takiej organizacji jest na niskim poziomie. Jednostka zyskuje więc stosunkowo stabilne środowisko pracy, w obrębie którego może realizować swoją karierę.

Tabela 3. Polityka personalna w modelu zarządzania zasobami ludzkimi

\begin{tabular}{|c|c|}
\hline $\begin{array}{c}\text { OBSZAR } \\
\text { POLITYKI } \\
\text { PERSONALNEJ }\end{array}$ & $\begin{array}{c}\text { DZIAŁANIA CHARAKTERYSTYCZNE } \\
\text { DLA MODELU }\end{array}$ \\
\hline $\begin{array}{l}\text { Podmiot działań } \\
\text { i rola pracownika }\end{array}$ & $\begin{array}{l}\text { Zasoby ludzkie mają znaczenie strategiczne } \\
\text { Podmiotem działań jest organizacja i jej cele, ale z } \\
\text { uwzględnieniem potrzeb pracownika }\end{array}$ \\
\hline $\begin{array}{l}\text { Polityka } \\
\text { zatrudnienia }\end{array}$ & $\begin{array}{l}\text { Planowanie zatrudnienia w perspektywie długookresowej } \\
\text { Rekrutacja i selekcja uwzględniająca kompetencje i posiadany } \\
\text { potencjał do rozwoju } \\
\text { Tendencja do długotrwałego wiązania pracownika z organizacją } \\
\text { Niska fluktuacja }\end{array}$ \\
\hline $\begin{array}{l}\text { Szkolenie } \\
\text { i rozwój }\end{array}$ & $\begin{array}{l}\text { Inwestowanie w rozwój pracownika } \\
\text { Tworzenie ścieżek kariery i możliwości doskonalenia } \\
\text { zawodowego } \\
\text { Możliwość awansu pionowego i poziomego } \\
\text { Szkolenie zarówno w zakresie umiejętności wykonawczych, jak } \\
\text { i społecznych } \\
\text { Odpowiedzialność za tempo i kierunek rozwoju przekazana } \\
\text { organizacji }\end{array}$ \\
\hline $\begin{array}{l}\text { Motywacja } \\
\text { i ocena }\end{array}$ & $\begin{array}{l}\text { Podejście zgodne z Teorią Y: ,ludzie chca pracować” } \\
\text { Wykorzystywanie finansowych i pozafinansowych instrumentów } \\
\text { motywacji } \\
\text { Motywacja przez zaangażowanie, partycypację i wzrost } \\
\text { odpowiedzialności } \\
\text { Ocena wykorzystująca mierniki ilościowe i jakościowe } \\
\text { Systematyczna ocena pracownika jako informacja zwrotna i } \\
\text { ważny element rozwoju }\end{array}$ \\
\hline
\end{tabular}

Źródło: Opracowanie własne.

Takie działania wydają się być korzystne dla pracownika. Zyskuje on kompetentnego partnera w postaci pracowników działu HR do planowania swojego rozwoju. Wystarczy realizować stawiane cele, podążać ścieżką kariery, by osiagnąć sukces zawodowy. Daje mu to poczucie bezpieczeństwa. Jest to jednak również pewnego rodzaju 
zagrożenie. Pracownik rozwija się w tempie i kierunku narzuconym przez organizację. Nie zawsze jest to wspólna droga. Czasami okoliczności zmuszają do odejścia. Wtedy jednostka musi odnaleźć się na zewnętrznym rynku pracy, gdzie na jej kwalifikacje i doświadczenie nie zawsze musi być zapotrzebowanie. Dlatego też warto w kontekście zachowań organizacyjnych rozważyć, w jaki sposób tak rozbudowany system $\mathrm{w}$ ramach organizacji może pomóc, a w jakich aspektach stanowić będzie zagrożenie dla dobrobytu jednostki.

Można tu jednak zauważyć istnienie pewnego paradoksu. Zachowanie pracownika $\mathrm{z}$ jednej strony cechuje bowiem aktywność, z drugiej zaś bierność. W wyniku presji otoczenia i działań organizacyjnych mamy do czynienia $\mathrm{z}$ kształtowaniem się postawy aktywności zawodowej - pracownik odbywa kursy, uczestniczy w szkoleniach, zdobywa nowe kwalifikacje, awansuje. Jednak jest to postawa pozbawiona samodzielności, to organizacja przejmuje kontrolę, szacuje potencjał i go rozwija. Jednostce bardzo często brakuje świadomości i wiedzy na temat konsekwencji takich działań. Nie każdy przecież musi być specjalistą w obszarze HR.

Środowisko rozwoju, jakie kształtuje organizacja, jest dla pracownika niepowtarzalną szansą. Może jednak skorzystać z niej w sposób optymalny tylko i wyłącznie pod warunkiem przyjęcia odpowiedzialności za własne losy - zarządzania własnym rozwojem zawodowym $^{20}$. Taka postawa wymuszona jest zresztą nie tylko przez wzgląd na dobro pracownika, ale również $\mathrm{z}$ uwagi na warunki funkcjonowania współczesnych organizacji i potrzeb kadrowych $\mathrm{z}$ nich wynikających. Jest to krok w kierunku organizacji przyszłości, o których będzie mowa w dalszej części rozdziału.

Rozwój zasobów ludzkich jest istotnym elementem systemu motywacji. W modelu tym funkcjonuje on na podstawie założenia, że ludzie chca pracować, trzeba im zatem stworzyć optymalne warunki, by zwiększając swój potencjał, działali na rzecz rozwoju organizacji. Wykorzystywanie pozafinansowych narzędzi motywacji oznacza nie tylko zmiany w zakresie treści i istoty pracy (np. poszerzanie zakresu odpowiedzialności, przeciwdziałanie monotonii), ale również działania w kierunku zwiększenia integracji pracownika $\mathrm{z}$ organizacja i zaspokajania potrzeb wyższego rzędu w środowisku organizacyjnym. Kształtuje to środowisko, w którym jednostka chce i lubi przebywać.

\footnotetext{
${ }^{20}$ Szerzej na temat zarządzania własnym rozwojem zawodowym por.: Januszkiewicz K. Rozwój zawodowy. Szanse i zagrożenia, Wydawnictwo Uniwersytetu Łódzkiego, Łódź 2008.
} 
Bardzo widoczna $\mathrm{w}$ ostatnich czasach jest również troska organizacji o integrację pracowników. Relacje formalne wzmacnia się nieformalnymi, w tych ostatnich upatrując często źródeł powodzenia. Wyraźnie pobrzmiewają tu echa zasady esprit de corps Fayola.

Co ciekawe, lojalność wobec zespołu traktowana jest jako priorytet. Stąd też weekendowe wyjazdy integracyjne, w ramach których koleżanki i koledzy z pracy poznają się lepiej również na gruncie prywatnym. Później w trakcie realizacji zadań zawodowych ów kapitał społeczny ma zaowocować lepszą współpracac. Rozważyć tu jednak należy dwa dylematy. Pierwszy dotyczy pytania, wobec kogo pracownik ma być lojalny. Wobec swojego zespołu (już badania Hawthworn wykazały, jak silna i destrukcyjna może to być norma) czy wobec organizacji, której cele powinny być priorytetem. Element ten często jest pomijany przez działy HR. Za priorytet uznaje się integrację, wzrost zaangażowania i budowanie atmosfery zaufania członków zespołu względem siebie, ustalanie hierarchii celów pozostawiając pracownikowi. Należy to uznać za zaniedbanie powodujące nieświadomość lub w gorszym wypadku ambiwalencję w stosunku do wynikających ze strategii zadań. Może to również nasilać zachowania agresywne. Wytworzy się rywalizacja i konkurencja między działami, zespołami zamiast współpracy i wsparcia $\mathrm{w}$ realizacji wspólnej przecież strategii organizacji.

Drugi ze wspomnianych dylematów dotyczy natomiast nastawienia pracowników do integracji. $\mathrm{W}$ obecnych czasach, gdy praca stanowi coraz ważniejszy element życia jednostki, warto postawić sobie pytanie o granice przenikania się świata prywatnego i zawodowego. Pogłębianie więzi społecznej czy emocjonalnej ze współpracownikami część osób przyjmuje niechętnie. Chcą $w$ nich widzieć kolegów, z którymi mają kontakt przez 8 godzin dziennie i łączą ich sprawy profesjonalne. Oczywiście przyjaźnie czy znajomości nawiązywane są również $\mathrm{w}$ środowisku organizacyjnym, jednak dla higieny i zdrowia psychicznego ważne jest jednak, aby poza tą domeną również prowadzić życie towarzyskie. Niechęć pracowników wobec integracji wynika również z faktu, że bardzo często działania takie planowane są na czas wolny od pracy. Na przykład wyjazdy weekendowe, jeszcze niedawno traktowane jako przywilej, coraz częściej są przyczyną niezadowolenia i krytyki ze strony pracowników. Przenikanie się domeny prywatnej oraz zawodowej może ponadto istotnie utrudniać skuteczną współpracę. Jest to szczególnie niebezpieczne dla menedżerów, których $\mathrm{z}$ jednej strony, zachęca się do deformalizacji relacji, skracania dystansu władzy (na przykład przez mówienie do siebie po imieniu czy znajomość sytuacji 
rodzinnej podwładnych), z drugiej jednak, oczekuje się obiektywizmu i stanowczości w procesie oceny i kontroli wyników. Szczególnie zaś $\mathrm{z}$ uwagi na miejsce, jakie element ten zajmuje w polityce ZZL.

System ocen $\mathrm{w}$ modelu zarządzania zasobami ludzkimi charakteryzuje się pewną specyfiką, przede wszystkim z uwagi na jego umiejscowienie w czasie. We współczesnych organizacjach mamy do czynienia zarówno z oceną bieżąca, jak i okresowa.

System ocen okresowych pracownika (SOOP) stanowi podstawę działań personalnych współczesnych organizacji. $\mathrm{Na}$ podstawie określonej procedury tworzy się proces, na początku którego ustalane są cele i zadania dla pracownika $\mathrm{w}$ danym okresie, na końcu zaś podsumowuje jego pracę i dokonuje oceny. System ten ma bardzo wiele zalet i trudno dziś zaproponować, zdaniem autorki, lepsze rozwiązanie. Punkty i wskaźniki zawarte w kwestionariuszach oceny są kompletną informacją dla pracownika, czego się od niego wymaga. Jasność i przejrzystość takiej informacji wpływa pozytywnie nie tylko na poczucie bezpieczeństwa, ale również na zaufanie względem pracodawcy. Jednak aby można było w pełni wykorzystać możliwości, jakie daje, należy zwrócić uwagę na kilka bardzo istotnych elementów.

Pierwszy postulat dotyczy przygotowania do wykorzystania SOOP-u. Tworzone przez specjalistów z działów personalnych narzędzie wykorzystywane jest przez osoby bez przygotowania specjalistycznego, a warto przecież zwrócić uwagę, że poza kontrolą wyników wiąże się z nim również aspekt psychospołeczny. Dlatego też konieczne wydają się szkolenia zarówno dla oceniających, jak i dla ocenianych, szczególnie że coraz częściej wykorzystuje się formułę oceny dwustronnej: pracownik konfrontuje dokonaną przez siebie ocenę własnej pracy $\mathrm{z}$ oceną przełożonego. W trakcie dialogu wypracowuje się wspólne stanowisko, a w razie braku porozumienia spisuje się raport rozbieżności. Taka otwartość bardzo sprzyja zaangażowaniu i wzajemnemu zaufaniu. Nie dokonuje się zaocznego rozliczenia wyników, a przekazuje informacje o tym, jak odbierane są starania pracownika w danym okresie. Buduje się partnerstwo, więc pracownik aktywnie może wpływać na swój wizerunek zawodowy i dbać o jego jakość.

Niebezpieczeństwo wiąże się jednak z łączeniem oceny okresowej $\mathrm{z}$ oceną bieżącą. Nieprzygotowani i niekompetentni menedżerowie dokonują oceny rocznej na podstawie wrażenia na temat pracy podwładnego $\mathrm{w}$ okresie bezpośrednio poprzedzającym SOOP. Wiedząc o tym, pracownicy bardziej się starają w tym okresie (co oczywiście samo w sobie nie jest niczym złym, jednak należy pamiętać o motywacji do pracy w dalszej części roku), mają jednak również często poczucie 
niesprawiedliwości, że ich wcześniejsze dokonania nie są brane pod uwagę tym bardziej, że otrzymywali na ich temat informacje na bieżąco.

Ocena bieżąca ma właśnie charakter informacji zwrotnej, przekazywanej podwładnemu przez bezpośredniego przełożonego. Daje ona pracownikowi wiedzę, jakie zachowania są pożądane, a jakich powinien unikać w przyszłości. Pozwala to na wykształcenie pewnej postawy i nawyków związanych $\mathrm{z}$ pracą $\mathrm{w}$ danym zespole $\mathrm{i} \mathrm{z}$ danym przełożonym. Jest to dla pracownika cenna lekcja, z której korzysta, często nawet $\mathrm{w}$ sposób nieświadomy ${ }^{21}$. W kontekście kształtowania organizacji warto zatem zadbać, by ocena bieżąca miała charakter informacji zwrotnej modelującej określone zachowania i w tym kierunku również edukować menedżerów. Postulat ten wydaje się szczególnie istotny w kontekście nacisku, jaki kładzie się na system ocen okresowych pracowników, przyznając mu wartość priorytetową $\mathrm{W}$ procesie zarządzania zasobami ludzkimi, podczas gdy ocena bieżąca, spotkania statutowe czy codzienna kontrola wyników również może być doskonałą okazją do modelowania zachowań. Tym lepszą, gdyby miała charakter systematyczny i przemyślany.

W polityce personalnej ukształtowanej przez model zarządzania zasobami ludzkimi organizacja realizuje swoje cele w perspektywie kilku lat. Pozwala to na zaplanowanie zasobów ludzkich mogących to umożliwić. Przyjęcie pracownika ze względu na potencjał, jakim dysponuje, i inwestycje $w$ jego rozwój sprawiają, że relację jednostka-organizacja można określić jako długotrwała. W idealnym układzie zarządzanie zasobami ludzkimi realizowane jest na podstawie procedur i narzędzi nie tylko skorelowanych ze strategią organizacji, ale również ją wspierających. System motywacji związany jest z oceną wyników, która wpływa na plany rozwoju pracownika. Powstaje oddzielny mechanizm w maszynie; Taylorowski „trybik” staje się podmiotem działania.

Jednak takie rozwiązania powoli przestają być wystarczające. Organizacje muszą stawić czoła coraz bardziej dynamicznym zmianom kształtującym nowy model polityki personalnej. Model tym ciekawszy, że możemy o nim jedynie dywagować, bez pewności, które przewidywania okażą się prawdziwe, a które nie.

\footnotetext{
${ }^{21}$ Być może pewnym nadużyciem jest odwołanie się w tym miejscu do prac z zakresy psychologii uczenia się i badań Skinnera nad mechanizmem warunkowania instrumentalnego. Jednak zdaniem autorki badania podstawowe często pozostają na uboczu rozważań, a ich wartość przy wyjaśnianiu podstaw zachowań człowieka jest przecież nieoceniona.
} 


\section{Kapitał ludzki w organizacji przyszłości}

Warunki, w jakich funkcjonują współczesne organizacje, zmuszają je do zmiany nie tylko w zakresie strategii, struktury czy procesów pracy, ale również $\mathrm{w}$ zakresie podejścia do pracowników. Planowanie zatrudnienia i zapewnianie rezerw kadrowych w perspektywie długookresowej już dziś staje się niemożliwe do realizacji. Konieczność elastyczności i szybkiego dopasowywania się do zmiennego otoczenia nakazuje organizacjom redefinicję roli pracowników w kontekście zasobów organizacyjnych. Przeobrażenia te stwarzają nowe warunki pracy jednostki, nowe zasady uczestnictwa i odpowiedzialności (por. Czekaj, Lisiński 2011). Trudno oczywiście jednoznacznie stwierdzić, jaki model polityki personalnej będzie obowiązywał w przyszłości. Zdaniem Cz. Zająca zmiany w obszarze zasobów ludzkich polegają na ujmowaniu tych zasobów w kategorii kapitału ludzkiego. $\mathrm{Na}$ gruncie teoretycznym znajduje to swoje odzwierciedlenie w koncepcji zarządzania kapitałem ludzkim. W praktyce natomiast przejawia się $\mathrm{W}$ wymaganiach stawianych pracownikom i menedżerom odnośnie do ich fachowości, elastyczności, sprawności, innowacyjności czy lojalności względem organizacji oraz zmianom oczekiwań jednostki względem środowiska pracy (Zając 2011, s. 307) ${ }^{22}$.

Zmiany te jednak są tak wyraźne, że opierając się na najbardziej symptomatycznych charakterystykach przekształceń współczesnych organizacji ${ }^{23}$ : koncentracji na kluczowych kompetencjach pracowników,

\footnotetext{
22 Większość organizacji dokonując zmian, wciąż funkcjonuje w paradygmacie zarządzania zasobami ludzkimi. Dlatego też omawiana w tej części perspektywa jutra może okazać się modyfikacją modelu ZZL wynikającą $\mathrm{z}$ adaptacji do nowych warunków. Może jednak również stanowić nową, odmienną jakość. Nie sposób więc dziś jednoznacznie przewidzieć, czy będzie to proces ewolucji, czy rewolucji. Dlatego też $\mathrm{w}$ niniejszym opracowaniu model polityki personalnej $\mathrm{w}$ organizacji przyszłości określony został zgodnie $\mathrm{z}$ tendencjami $\mathrm{w}$ literaturze przedmiotu jako zarządzanie kapitałem ludzkim.

${ }_{23}$ Wybór takich charakterystyk nie jest przypadkowy. W literaturze przedmiotu funkcjonuje szereg odmiennych opisów współczesnych organizacji. Jednak z uwagi na przedmiot rozważań i zakres prowadzonych analiz właśnie te trzy cechy uznano za najbardziej istotne i wokół nich kolejno prowadzone będą dywagacje. Należy jednak wskazać, iż dywagacje dotyczące polityki personalnej uwzględniają fakt, że podejście do zarządzania i organizacji pracy, typowe dla danego kontekstu kulturowego, nie będzie takie samo w innym kontekście pomimo rozwoju technologii i tendencji w kierunku ujednolicenia zarządzania. Menedżerowie z różnych krajów posiadać mogą podobny teoretyczny bagaż, jednak jego praktyczne wykorzystanie zawsze odbywać się będzie w kontekście kultury danego kraju, jego historii, wartości, zwyczajów, modyfikując istotnie zachowania organizacyjne (szerzej na ten temat por. Kostera, Śliwa 2010, s. 73-76).
} 
wykorzystywaniu elastycznych form zatrudnienia oraz wirtualizacji pracy, można antycypować, jaki będzie ich wpływ na politykę personalną, a tym samym na zachowania ludzi w organizacji (por. tab. 4).

Tabela 4. Polityka personalna w modelu jutra

\begin{tabular}{|l|l|}
\hline \multicolumn{1}{|c|}{$\begin{array}{c}\text { OBSZAR } \\
\text { POLITYKI } \\
\text { PERSONALNEJ }\end{array}$} & \multicolumn{1}{c|}{\begin{tabular}{c}
\multicolumn{1}{c|}{ DZIAŁANIA CHARAKTERYSTYCZNE } \\
DLA MODELU
\end{tabular}} \\
\hline $\begin{array}{l}\text { Podmiot działań } \\
\text { i rola pracownika }\end{array}$ & $\begin{array}{l}\text { Zasoby ludzkie mają znaczenie strategiczne/eksternalizacja } \\
\text { zatrudnienia } \\
\text { Podmiotem działań jest organizacja i jej cele, współpraca } \\
\text { z pracownikami nawiązywana jest adekwatnie do nich }\end{array}$ \\
\hline $\begin{array}{l}\text { Polityka } \\
\text { zatrudnienia }\end{array}$ & $\begin{array}{l}\text { Planowanie zatrudnienia w perspektywie krótkookresowej (z } \\
\text { wyjątkiem wybranych, kluczowych obszarów) } \\
\text { Rekrutacja i selekcja uwzględniające ściśle określone } \\
\text { kompetencje } \\
\text { Wysoka fluktuacja }\end{array}$ \\
\hline Szkolenie i rozwój & $\begin{array}{l}\text { Inwestowanie w rozwój ,kompetencji kluczowych”, w przypadku } \\
\text { pozostałych pracowników organizacja poszukuje osób } \\
\text {,kompletnych” } \\
\text { Kierunek i tempo rozwoju zależne od pracownika }\end{array}$ \\
\hline Motywacja i ocena & $\begin{array}{l}\text { Podejście zgodne z Teorią Z }{ }^{24} \text { :, ,ludzie chca pracować i nie chcą } \\
\text { pracować, dlatego też należy zatrudniać tych pierwszych” } \\
\text { Wykorzystywanie finansowych i pozafinansowych instrumentów } \\
\text { motywacji } \\
\text { Ocena wyników pracy }\end{array}$ \\
\hline
\end{tabular}

Źródło: Opracowanie własne.

Koncentracja na kluczowych kompetencjach pracowników z punktu widzenia organizacji oznacza tak naprawdę koncentrację na kompetencjach i poszukiwanie pracowników, którzy w danym momencie mogą się nimi wylegitymować. Prowadzi to w konsekwencji do podziału na pracowników klasy A, B i C oraz stanowiska klasy A, B i C (Huselid, Beatty, Becker 2006, s. 78). Stanowiska klasy A, określane jako strategiczne, mają bezpośredni wpływ na działalność organizacji, stanowiska B mają charakter wspierający, natomiast klasy $\mathrm{C}$ mogą mieć wpływ na funkcjonowanie organizacji, ale nie $w$ jej wymiarze strategicznym.

O sukcesie organizacji decyduje właściwe zidentyfikowanie kluczowych stanowisk pracy, a następnie podejmowanie takich działań, by odpowiedni ludzie znaleźli się na odpowiednich stanowiskach przez

${ }^{24}$ Teoria Z jest autorskim rozwinięciem Teorii XY McGregora, uwzględniającym zarówno podmiotowość jednostki, jak i organizacji. 
odpowiedni czas. Działanie racjonalne i uzasadnione. Takie podejście powoduje jednak również inną konsekwencję - poza klasą A różnicowane są kategorie B i C. Zarządzanie zdywersyfikowanym w ten sposób portfelem stanowisk zakłada ich koordynację, jednak sukces zależy od stanowisk A i dlatego to ich głównie dotyczą inwestycje. Często diagnozie takiej towarzyszą dodatkowe zapisy umowy o pracy, w których pracownicy określani jako ,potencjał retencyjny” otrzymują dodatkowe uposażenie $\mathrm{w}$ zamian za pozostanie $\mathrm{w}$ firmie przez określony czas. Nie oznacza to ignorowania pozostałych grup, przy czym B traktowana jest w sposób szczególny, jako wspierająca A i źródło ewentualnego potencjału sukcesji, natomiast stanowiska klasy $\mathrm{C}$ - jako niestrategiczne, z czasem zostają wyeliminowane bądź przeniesione na zewnątrz.

Pracownicy stanowiący trzon załogi mają zatem zapewnić firmie stabilność zatrudnienia, natomiast pracownicy wchodzący w skład drugiego segmentu - elastyczność zatrudnienia i mają stanowić swoisty bufor chroniący podstawowy zasób ludzki, który ma dla organizacji znaczenie strategiczne (Dobrowolska 2007, s. 169).

Autorzy koncepcji różnicowania stanowisk wskazują, iż istnieje zasadnicza różnica między sprawiedliwością a równością $\mathrm{w}$ kapitale ludzkim. Procedury kadrowe ewoluujące w kierunku równego traktowania wszystkich pracowników obecnie, w dobie wzmożonej konkurencji muszą traktować każdego zgodnie $\mathrm{z}$ jego wkładem w osiaganie celów organizacji. Takie działania, zmierzające do „rozluźnienia więzi” z pracownikami, podyktowane są oczywiście rachunkiem ekonomicznym. Poprzez elastyczność zatrudnienia/kompetencji i właściwe nimi zarządzanie organizacja zapewnia sobie współpracę z tymi, którzy aktualnie zaspokajają potrzeby kadrowe. Na taką właśnie adekwatność pozwala druga $\mathrm{z}$ wymienionych na wstępie charakterystyk - wykorzystywanie elastycznych form zatrudnienia. Coraz częściej zamiast pracowników w tradycyjnym znaczeniu tego słowa organizacje wykorzystują formułę ,partnerów czasowych" (np. zatrudnienie na podstawie umowy-zlecenia, umowy o dzieło).

Podmioty zainteresowane elastycznymi formami zatrudnienia zawierają między sobą nietypowy stosunek pracy, charakteryzujący się wykonywaniem pracy niestałej, w niepełnym wymiarze czasu pracy, bez pełnego zabezpieczenia socjalno-pracowniczego lub też o ograniczonym prawie do tych świadczeń, często wykonywanej poza siedzibą firmy (Auriga za: Myjak, Myjak 2006, s. 245). Poza zaletami takiego kształtowania stosunku pracy, leżącymi po stronie organizacji, wykorzystywanie elastycznych form zatrudnienia wydaje się również 
korzystne dla samego pracownika. Stwarza bowiem możliwości do samodzielnego zarządzania własną karierą zawodową i korelacji jej z innymi domenami życia. Taka organizacja pracy przynosi także szereg dodatkowych możliwości, wśród których wymienić można:

- aktywizację grup wykluczonych z tradycyjnego stosunku pracy (np. studenci i osoby uczące się, emeryci, renciści, osoby o niskich kwalifikacjach, osoby o bardzo wysokich kwalifikacjach, jednak bardzo rzadkich, osoby samotne wychowujące dzieci lub mające pod pieką inne osoby zależne),

- łączenie różnych form zatrudnienia $\mathrm{i}$ związaną $\mathrm{z}$ tym dywersyfikację źródeł zarobkowych,

- równoległą realizację innych zadań (np. studia, kursy etc.),

- wykonywanie pracy w domu (korzystne szczególnie dla osób wychowujących dzieci, osób niepełnosprawnych, przewlekle chorujących etc.),

- decydowanie o czasie i miejscu wykonywania zadań.

Jednak pomimo silnych argumentów wskazujących na pozytywny wymiar zmian w formach zatrudnienia warto mieć na uwadze ich wpływ na zachowania organizacyjne i konsekwencje z nimi związane.

$\mathrm{Za}$ najbardziej istotny należy uznać brak poczucia pewności i stabilności zatrudnienia, uniemożliwiający planowanie i wyznaczanie celów nie tylko w sferze zawodowej, ale również osobistej. Związane $\mathrm{z}$ tym ograniczenia $\mathrm{w}$ regularnym rozwoju zawodowym uniemożliwiają długookresowe planowanie kariery, a co się z tym wiąże - również rodziny (por. Adamkiewicz 2005, s. 145).

Brak klarownej i stałej sytuacji finansowej może ponadto powodować zmiany w sferze ekonomicznej, m.in. obniżenie zarobków, przyszłej emerytury, brak stałego dostępu do niektórych świadczeń socjalnych, utrudnienia w korzystaniu np. z kredytów bankowych. Elementy te przekładają się w sposób oczywisty na sferę życia osobistego. Jedną $\mathrm{z}$ najczęściej przytaczanych przyczyn odkładania decyzji o zawieraniu związków małżeńskich jest brak stabilnej sytuacji finansowej (związanej z pracą) oraz chęć posiadania potomstwa dopiero w chwili osiagnięcia satysfakcjonującej pozycji zawodowej. Oczywiście przyczyną takich deklaracji oprócz względów finansowych są również przemiany społeczne, których konsekwencją jest propagowany model: spełnienie zawodowe - spełnienie osobiste. Nie dociekając, które zjawisko jest względem drugiego pierwotne, należy uznać, iż brak pewności i stałości zatrudnienia wpływa ograniczająco nie tylko na 
możliwości i chęci rozwoju w sferze zawodowej, ale również osobistej (Błaszczyk, Januszkiewicz, Śmigielski 2006, s. 98).

Zmiany $w$ zakresie polityki personalnej prowadzonej przez organizacje korespondują ze zmianami w postrzeganiu i realizacji kariery zawodowej przez jednostkę. Nowy paradygmat kariery, określanej jako kariera bez granic, wymusza zmiany w zakresie tożsamości zawodowej, rozumianej jako część tożsamości, ogólnego obrazu JA, związanej z pracą zawodową (Strykowska 2007, s. 18).

W kontekście związku z organizacją pracownik może wytworzyć w sobie poczucie tożsamości organizacyjnej - będzie wówczas identyfikował się z organizacją i jej celami. Rozwój zawodowy przebiega wtedy w ramach ścieżki kariery wypracowanej przez firmę. Jednostka może jednak również identyfikować się z własną grupą zawodowa, wówczas wytworzy tożsamość profesjonalnq, nie związaną z organizacja, lecz ze schematem poznawczym i skryptami ją charakteryzującymi. W tym przypadku to one decydują o drodze rozwoju, jego realizacji i stopniu integracji z organizacją. Trzecia forma, zakładająca realizację własnej wizji rozwoju zawodowego, określa tożsamość zawodowa jednostka aktywnie i samodzielnie zarządza swoją kariera, uczestnictwo w kolejnych organizacjach traktując jako zadania do wykonania ${ }^{25}$.

Tak rozumiana tożsamość zawodowa wydaje się być czymś pożądanym w obecnych czasach, gdy organizacje chcą wykorzystywać pracowników w formie i zakresie adekwatnym do ich potrzeb, a jednostki poszukuja nowych form samorealizacji zawodowej. Nieuzasadnione sa zatem pojawiające się $\mathrm{w}$ literaturze przedmiotu pejoratywne określenia takiej formy uczestnictwa pracownika. Podczas gdy funkcjonująca na takich zasadach organizacja postrzegana jest jako nowoczesna, elastyczna i zdolna od szybkiej reakcji na wyzwania otoczenia, jednostki pracujacce w taki sposób określa się jako osoby o mentalności najemników, bez woli integracji i chęci identyfikacji z celami organizacji matki.

Należy jednak pamiętać, że w warunkach dużej ruchliwości społecznej, tworzenia doraźnych koalicji i konieczności szukania kompromisowych rozwiązań w zakresie konstruowania własnej ścieżki zawodowej w zasadzie wskazana jest tożsamość zawodowa. Pracownik często zmieniający swoją przynależność do zespołu zadaniowego, zarówno w ramach organizacji, jak i na szeroko rozumianym rynku pracy, współpracujący z ludźmi reprezentującymi różne kultury i wartości ma

\footnotetext{
${ }^{25}$ Zaproponowany podział na tożsamość organizacyjnq, profesjonalnq $i$ zawodowa, jest podziałem autorskim, opracowanym na podstawie koncepcji psychologii różnic indywidualnych i osobowości.
} 
coraz mniej podstaw do trwałej identyfikacji z określoną grupą. O jego funkcjonowaniu decyduje raczej orientacja na osiagnięcia i własny rozwój. Cele te mogą być skutecznie osiagane tylko dzięki umiejętności zawierania nowych koalicji i „odnajdywania się” w nowym środowisku. Wykształcenie tożsamości zawodowej (indywidualnej) chroni go przed częstym przeżywaniem kryzysów związanych z odejściem z organizacji i jest przejawem postawy proaktywnej, będącej najbardziej optymalnym sposobem przystosowania się do aktualnych warunków (por. Strykowska 2007, s. 35).

Pracownik nie musi już wiązać swojego losu z jednym zakładem pracy przez całe życie. Często zostaje współpracownikiem tego, który daje więcej, użytecznym tak długo, jak długo osiaga dobre wyniki. Staje się lojalny przede wszystkim wobec samego siebie, dopiero potem względem grupy najbliższych lub obecnych współpracowników, a dopiero na końcu, i to w niewielkim stopniu - do zakładu pracy. Praca taka sprzyja tworzeniu się kultury wybujałego indywidualizmu (Jasiński 2004, s. 55). Jest to jednak zjawisko wynikające również z metamorfozy samej organizacji i próby dostosowania się jednostki do nowej polityki personalnej, znalezienia swojego miejsca w systemie. Jak każdy przełom, działania takie wymagają dookreślenia zasad współdziałania obydwu stron.

Zmiany w zakresie polityki personalnej i wykorzystywanie elastycznych form zatrudnienia wpływają również w sposób istotny na formę relacji pracownik-organizacja. Dotychczas promowane działania koncentrowały się wokół silnej socjalizacji jednostki w ramach zakładu pracy. Koncepcja przywiązania/zaangażowania organizacyjnego w ujęciu ZZL określała zasady i kryteria przystosowania funkcjonalnego, opartego na „starym” kontrakcie psychologicznym (por. tab. 5). Obecnie rozwój organizacji zmierza w kierunku ,organizacji cynicznych”, opierających swój rozwój na „nowym” kontrakcie psychologicznym, którego cechą wyróżniająca jest brak silnej i stabilnej więzi afektywnej. Adaptacja funkcjonalna w starym systemie będzie dysfunkcjonalna w nowym i odwrotnie [Bańka 2007, s. 71]. 
Tabela 5. Wybrane przejawy adaptacji funkcjonalnej i dysfunkcjonalnej

\begin{tabular}{|c|c|c|}
\hline & Adaptacja funkcjonalna & Adaptacja dysfunkcjonalna \\
\hline 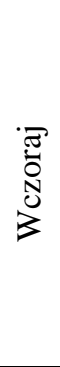 & $\begin{array}{l}\text { - } \quad \text { Lojalność wobec organizacji } \\
\text { - } \quad \text { aangażowanie w pracę wyłącznie } \\
\text { Adaptacja do zmiany przez ewolucję } \\
\text { w ramach środowiska } \\
\text { organizacyjnego i transformację } \\
\text { własnej osoby przez zmianę } \\
\text { dopasowaną do środowiska } \\
\text { wewnatrzorganizacyjnego }\end{array}$ & $\begin{array}{ll}\text { - } & \text { Fluktuacja, zmiana pracy } \\
\text { i organizacji } \\
\text { Kariera bez granic } \\
\text { (podejmowanie zatrudnienia w } \\
\text { poprzek zawodów, ról, } \\
\text { organizacji) } \\
\text { Szeroka specjalizacja w różnych } \\
\text { domenach życia etc. }\end{array}$ \\
\hline $\begin{array}{c}\stackrel{0}{\Xi} \\
\stackrel{\Xi}{\Xi} \\
\frac{n}{N} \\
\stackrel{n}{D}\end{array}$ & 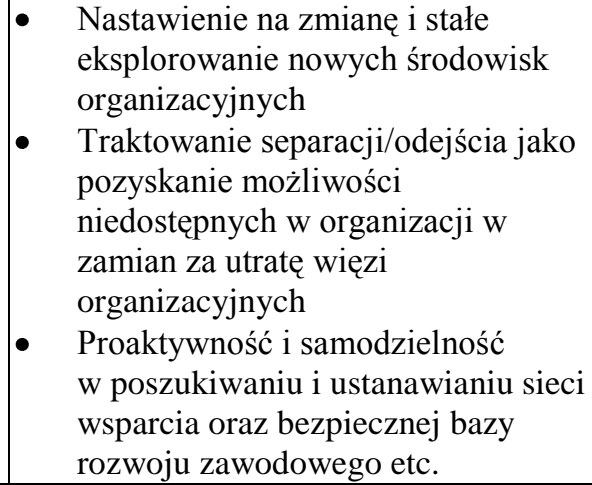 & $\begin{array}{l}\text { Nadmierne przywiązanie do } \\
\text { organizacji jako miejsca i } \\
\text { środowiska personalnego } \\
\text { Lęk przed separacja } \\
\text { zwolnieniem } \\
\text { Trzymanie się starej koncepcji } \\
\text { kariery }\end{array}$ \\
\hline
\end{tabular}

Źródło: Opracowanie własne na podstawie: Bańka, Wołowska 2007, s. 71-73.

Zmiana rzeczywistości organizacyjnej wymaga redefinicji, czym jest adaptacja funkcjonalna i dysfunkcjonalna, oraz wypracowania nowej metodologii schematów adaptacyjnych na poziomie indywidualnym i organizacyjnym. Obecnie w ten szczególny sposób kształtuje się więzi z pracownikami posiadającymi kluczowe kompetencje. Pozostałych uczestników - czasowych zwykło się traktować instrumentalnie. Ich umiejętności, kompetencje, zaangażowanie wykorzystywane są adekwatnie do potrzeb organizacji. Tu nie ma już mowy o silnej i solidarnej integracji i adaptacji. Uzasadniona w tym przypadku jest chyba konstatacja o wtórnym uprzedmiotowieniu pracownika.

Istotne zmiany widać również w procesie motywacji. Stosowanie rozbudowanego, spójnego systemu uniemożliwiać może bowiem z jednej strony, segmentacja zatrudniania, w przypadku której pracownicy zakwalifikowani do różnych grup moga liczyć na równe wsparcie i zaangażowanie ze strony organizacji. Z drugiej zaś, związana z nią wirtualizacja stosunków $\mathrm{z}$ niektórymi dostawcami usług (np. określona formuła outsourcingu pracowniczego). Jest to utrudnione $\mathrm{z}$ uwagi na konieczność uwzględnienia dwóch płaszczyzn: 
- centralnej, wyznaczającej ramy systemu motywacyjnego danej organizacji;

- peryferyjnej, obejmującej indywidualne systemy motywacyjne partnerów (dostawców usług).

Sprawę dodatkowo komplikuje fakt, że określony dostawca usług może wchodzić w teoretycznie nieskończoną liczbę związków wirtualnych i należeć do różnych systemów motywacyjnych. Skuteczność systemu gwarantuje $\mathrm{w}$ tej sytuacji jego uproszczenie i rezygnacja z zaawansowanych narzędzi i instrumentów [Gableta, Pietroń-Pyszczek 2004, s. 45]. Tak więc dla menedżerów, a w szczególności menedżerów personalnych nowe formy zatrudnienia stanowia nowe wyzwania i pytania o narzędzia zarządzania i motywowania pracowników, z którymi kontakt jest ograniczony do kontaktu ,wirtualnego, a narzędzia motywacyjne oparte na bezpośrednich relacjach są ograniczone lub nawet wykluczone" [Lenart 2006, s. 233].

Zaprezentowana powyżej analiza polityki personalnej organizacji tradycyjnej, współczesnej i ,jutra" oraz ich wpływu na zachowania organizacyjne skłania do refleksji na temat zmiany w zakresie sposobu rozumienia istoty $\mathrm{i}$ znaczenia pracownika dla organizacji. Ponieważ istotnym przeobrażeniom ulegają $\mathrm{w}$ tej sytuacji obydwa podmioty, trudno dziś jednoznacznie wskazać, jaki będzie kształt polityki personalnej w przyszłości. $Z$ całą pewnością będzie ona zależeć od rodzaju organizacji i ludzi, którzy znajdą w niej swoje miejsce, będzie jednak również ulegać modyfikacjom pod wpływem innych czynników organizacyjnych.

\section{Bibliografia}

1. Adamkiewicz J., Praca zawodowa problemem życia rodzinnego, w: B. Pietrulewicz, Współczesne problemy edukacji, pracy izatrudnienia pracowników, Zakład Poligrafii EURODRUK, Zielona Góra 2005.

2. Armstrong M., Zarzqdzanie zasobami ludzkimi, Oficyna ekonomiczna, Dom Wydawniczy ABC, Kraków 2001.

3. Babbage Ch., O podziale pracy, za: J. Kurnal (red.), Twórcy naukowych podstaw organizacji. Wybór pism, PWE, Warszawa 1972.

4. Bańka A., Wołowska A., Geneza i rozwój pojęcia przywiqzania, w: M. Strykowska (red.), Funkcjonalne $i$ dysfunkcjonalne zjawiska organizacyjne, Wydawnictwo Naukowe Uniwersytetu Adama Mickiewicza, Poznań 2007.

5. Bartkowiak G., Psychologia $w$ zarzadzaniu. Nowe spojrzenie, Wydawnictwo Uniwersytetu Ekonomicznego w Poznaniu, Poznań 2010.

6. Błaszczyk W., Januszkiewicz K., Śmigielski J., Oblicza jakości życia. Człowiek w sytuacji pracy, Wydawnictwo Uniwersytetu Łódzkiego, Łódź 2006. 
7. Bohdziewicz P., Kariery zawodowe $w$ gospodarce opartej na wiedzy (na przykładzie grupy zawodowej informatyków), Wydawnictwo Uniwersytetu Łódzkiego, Łódź 2008.

8. Czekaj J., Lisiński M., Rozwój koncepcji i metod zarzq̨dzania, Wydawnictwo: Fundacja Uniwersytetu Ekonomicznego w Krakowie, Kraków 2011.

9. Dobrowolska M., w: Perspektywy psychologii pracy, red. M. Górnik-Durose, B. Kożusznik, Wydawnictwo Uniwersytetu Śląskiego, Katowice 2007.

10. Fayol H., Ogólne zasady administracji, za: J. Kurnal, Twórcy naukowych podstaw organizacji. Wybór pism, PWE, Warszawa 1972.

11. Gableta M., Pietroń-Pyszczek A., Funkcjonowanie pracownika w wirtualnych warunkach gospodarowania,

12. Hislop D., Axtell C., Daniels K., The challenge of remote working, w: S. Susan, C. L. Cooper (red.), Personnel psychology, Oxford University Press, New York 2008.

13. Huselid M. A., Beatty R. W., Becker B. E., Gracze klasy A czy stanowiska klasy A. Nowe strategiczne podejście do zarzqdzania zasobami ludzkimi, „Harvard Business Review Polska" 2006, nr 11.

14. Januszkiewicz K. Rozwój zawodowy. Szanse $i$ zagrożenia, Wydawnictwo Uniwersytetu Łódzkiego, Łódź 2008.

15. Jasiński Z., Telepraca i zespoły wirtualne, w: Z. Wiśniewski, A. Pocztowski (red.), Zarzqdzanie zasobami ludzkimi w warunkach nowej gospodarki, Oficyna Ekonomiczna, Kraków 2004.

16. Juchnowicz M., Motywacyjne aspekty zarzadzania, w: M. Juchnowicz (red.), Zarzqdzanie zasobami pracy - strategia i instrumentarium, Oficyna Wydawnicza Szkoły Głównej Handlowej, Warszawa 1996.

17. Kożusznik B., Zachowanie człowieka $w$ organizacjach wiedzy, w: L. ZbiegieńMaciąg, E. Beck (red.), Zarzqdzanie ludźmi w otoczeniu globalnym - pomiędzy „starym” a ,nowym”, Uczelniane Wydawnictwo Naukowo-Dydaktyczne, Kraków 2006.

18. Lenart M., E-zarzadzanie zasobami ludzkimi, w: L. Zbiegień-Maciąg, E. Beck (red.), Zarzqdzanie ludźmi w otoczeniu globalnym - pomiędzy ,starym” a „,nowym”, Uczelniane Wydawnictwo Naukowo-Dydaktyczne, Kraków 2006.

19. Listwan T., Przedmiot, ewolucja $i$ znaczenie zarzadzania kadrami, w: T. Listwan (red.), Zarzadzanie kadrami, C.H. Beck, Warszawa 2010.

20. E. Mayo, Pierwsze badania oraz Hawthorne $i$ Western electric Company, wybór tekstów zamieszczony w: J. Kurnal (red.), Twórcy naukowych podstaw organizacji. Wybór pism, PWE, Warszawa 1972.

21. Myjak T., Myjak S., Praktyka elastycznych form zatrudnienia $i$ ich wplyw na funkcjonowanie jednostki w organizacji, w: L. Zbiegień-Maciagg, E. Beck (red.), Zarzadzanie ludźmi w otoczeniu globalnym - pomiędzy ,starym” a ,nowym”, Uczelniane Wydawnictwo Naukowo-Dydaktyczne, Kraków 2006.

22. Oleksyn T., Zarzqdzanie zasobami ludzkimi $w$ organizacji - kanony, realia, kontrowersje, Wolters Kluwer, Warszawa 2008.

23. Pocztowski A., Zarzqdzanie zasobami ludzkimi, PWE, Warszawa 2008.

24. Robbins S. P., Coulter M., Management, Library of Congress Cataloging-inPublication Data, Prentice-Hall International Ltd., London 2004.

25. Rogovsky N., Restructuring for corporate success. A socially sensitive approach, International Labour Office, Geneva 2005. 
26. Strykowska M., Adaptacyjna funkcja tożsamości zawodowej, w: M. Strykowska (red.), Funkcjonalne $i$ dysfunkcjonalne zjawiska organizacyjne, Wydawnictwo Naukowe Uniwersytetu Adama Mickiewicza, Poznań 2007.

27. Szałkowski A., Wprowadzenie do zarzqdzania personelem, Wydawnictwo Akademii Ekonomicznej, Kraków 2000.

28. Taylor F., Zasady naukowego zarzqdzania, za: J. Kurnal (red.), Twórcy naukowych podstaw organizacji. Wybór pism, PWE, Warszawa 1972.

29. Wiernek B., Personel firmy jako zasób strategiczny, w: L. Zbiegień-Maciąg (red.), Nowe tendencje $i$ wyzwania $w$ zarzadzaniu personelem, Oficyna Ekonomiczna, Kraków 2006.

30. Wojalski M. Z., 575 lat miasta Łodzi, Łódź 1998.

31. Zając Cz., Kapitat ludzki jako czynnik rozwoju przedsiębiorstwa w świetle współczesnych koncepcji zarzqdzania, w: B. Nogalski, B. Wierzbicka, Systemowe aspekty zarzqdzania organizacjami. Prace $i$ materiaty Wydziału Zarzadzania Uniwersytetu Gdańskiego 4/1/2011, Fundacja Rozwoju Uniwersytetu Gdańskiego, Sopot.

\section{Spis tabel}

Tabela 1. Wytyczne dla polityki personalnej w ogólnych zasadach administracji H.Fayola

Tabela 2. Polityka personalna w modelu administrowania zatrudnieniem

Tabela 3. Polityka personalna w modelu zarządzania zasobami ludzkimi

Tabela 4. Polityka personalna w modelu jutra

Tabela 5. Wybrane przejawy adaptacji funkcjonalnej i dysfunkcjonalnej 